\title{
Penggunaan Metode Make And Match Dalam Meningkatkan Pemahaman Usaha Persiapan Kemerdekaan Pada Siswa SMP Negeri 2 Siak Hulu
}

\author{
MARULAM SINAGA \\ Dinas Pendidikan Kabupaten Kampar \\ SMP Negeri 2 Siak Hulu \\ E-mail : marulamsinaga@gmail.com
}

\begin{abstract}
Learning and understanding the effort to prepare for independence in the lessons taught by the teacher to students sometimes makes the teacher experience obstacles in order to achieve learning outcomes. Students still do not understand and also misunderstand the meaning of independence for the Indonesian people. This classroom action research applies the make and match method that seeks to match the understanding students have in learning. Through action research and also qualitative analysis, it can be produced that the use of make and match methods can improve students' understanding of independence preparation efforts and this gives students a positive attitude in following the subject matter.
\end{abstract}

Keywords: Effort for Independence Preparation, Make and Match Method

Harapan yang diinginkan masyarakat terhadap dunia pendidikan adalah pendidikan yang bermutu. Peningkatan mutu pendidikan dapat dicapai dengan peran aktif guru di sekolah. Guru berperan penting dalam proses belajar mengajar oleh karenanya, perlu upaya meningkatkan kualitas di samping kuantitas guru. Berbicara masalah kualitas mengajar guru dari waktu ke waktu terus mengalami perubahan dan perkembangan.

Dewasa ini dunia pendidikan terus berusaha dan meningkatkan kualitas gurunya melalui penemuan-penemuan metode pengajaran yang tepat dalam artian efektif dan efisien.Penerapan metode pengajaran bagi guru menjadikan nilai tambah dalam mengajar, selain dapat menghindari guru mengajar dengan metode yang monoton, juga dapat memberikan pembelajaran baru bagi guru dalam memberikan pembelajaran secara efektif dan efisien kepada peserta didik.

Selain itu juga kondisi ini akan meningkatkan kepuasan guru dalam menstranfer ilmu pengetahuannya. Kepuasan seorang guru dalam memberikan pelajaran dianggap penting, yaitu dalam hal menghasilkan siswa yang berkualitas. Sebab gurulah pelaksana terdepan dan ujung tombak di lapangan pendidikan khususnya di kelas. Berhasil atau tidaknya upaya peningkatan mutu pendidikan banyak ditentukan oleh kemampuan yang ada pada guru tersebut dalam mengembangkan tugas pokok sehari-hari.

Perubahan dunia pendidikan yang makin pesat, telah mengakui eksistensi seorang guru secara individual yang harus mendapatkan perhatian dari banyak kalangan. Perhatian ini seperti dari pemerintah, yakni sebagai pihak yang membutuhkan tenaga pengajar kemudian masyarakat sebagai pihak yang memerlukan seorang berilmu untuk memberikan ilmunya kepada anak-anak mereka.

Guru merupakan sumberdaya yang sangat berperan dalam memberikan pelayanan pendidikan kepada peserta didik, guru ini merupakan ujung tombak pelayanan kepada peserta didik, dimana pengajaran langsung diberikan oleh guru kepada peserta didik. Oleh karenanya kepuasan guru dalam memberikan pelajaran kepada peserta didik dirasakan 
penting dan perlu mendapatkan perhatian dari berbagai kalangan karena akan memberikan dampak pada pelayanan yang diberikannya kepada peserta didik.

Salah satu permasalahan yang dihadapi guru khususnya dalam mengajar mata pelajaran IPS, hampir sama yakni siswa kurang tertarik mengikuti pelajaran karena dianggap pelajarannya begitu-begitu saja dan diulang-ulang dari zaman dahulu. Hal ini memberikan nilai buruk pada guru dalam mengajar mata pelajaran IPS.Seperti masalah sejarah terbentuknya kesadaran nasional dan perkembangan pergerakan kebangsaan Indonesia merupakan pelajaran yang membosankan bagi siswa dalam mempelajaarinya.

Sejarah ini terkesan sebagai dongengan yang diajarkan kepada siswa dan guru juga merasa kurang mendapatkan tantangan dalam memberikan pelajaran, hal ini dikarenakan siswa yang kurang tertarik.Sesui dengan topik bahasan yang dilakukan pada siswa kelas VIII di SMP Negeri 2 Siak Hulu dengan tujuan pembelajaran yang diharapkan bahwa setelah mempelajaari materi tersebut siswa diharapkan mampu menjelaskan perbedaan perspektif antar kelompok sekitar proklamasi kemerdekaan indonesia, kemudian juga mampu menjelaskan kronologi proklamasi kemerdekaan indonesia, mampu mengidentifikasi penyebaran berita proklamasi kemerdekaan melalui berita radio, pamphlet dan selebaran dan mampu menjelaskan dukungan dari berbagai daerah berupa dukungan spontan dan tindakan heroik dari berbagai daerah.

Namun pada kenyataannya capaian hasil belajar jauh dari yang diharapkan, dimana KKM yang ditetapkan sebesar 73 sedangkan capaiannya hanya mencapai 50 . Selain daripada itu masalah karakter siswa yang diharapkan setelaha belajar sejarah ini antara lain menimbulkan semangat kebangsaan dan juga menghargai prestasi dan gemar membaca masih jauh dari harapan. Sebagaimana dilihat dari observasi lapangan kepada siswa, bahwa siswa kurang memiliki semangat kebangsaan terhadap bangsa ini hal ini dilihat dari pesimistis terhadap perkembangan bangsa dan juga kurang menghargai prestasi para pejuang yang telah memperjuangkan kemerdekaan yang ditunjukkan dari kurangnya memperhatikan dan juga mendengarkan materi pelajaran dan kurangnya kegemaran membaca bagi siswa dalam membaca sejarah.

Untuk menghindari salah pengertian atau salah tafsir tentang makna istilah yang digunakan dalam penelitian ini, maka perlu dijelaskan makna beberapa definisi operasional sebagai berikut : Prestasi belajar adalah hasil belajar yang dicapai siswa dalam mengikuti pembelajaran peristiwa disekitar proklamasi dan pembentukan NKRI dengan capaian nilai dan juga sikap perilaku yang dihasilkan seperti semangat kebangsaan. IPS adalah mata pelajaran yang mengkaji seperangkat peristiwa, fakta, konsep, generalisasi yang berkaitan dengan isu sosial serta berfungsi untuk mengembangkan pengetahuan, nilai, sikap, dan keterampilan siswa tentang masyarakat, bangsa, dan negara Indonesia (Depdiknas, 2004). Metode make and match adalah system pembelajaran yang mengutamakan penanaman kemampuan social terutama kemampuan bekerja sama, kemampuan berinteraksi disamping kemampuan berfikir cepat melalui permainan mencari pasangan dengan dibantu kartu.

Mata pelajaran Ilmu Pengetahuan Sosial (IPS) berfungsi untuk mengembangkan pengetahuan, nilai, sikap, dan keterampilan siswa tentang masyarakat, bangsa, dan negara Indonesia (Puskur Balitbang Depdiknas, 2003).Terkait dengan tujuan mata pelajaran IPS yang sedemikian fundamental maka guru dituntut untuk memiliki pemahaman yang holistik dalam upaya mewujudkan pencapaian tujuan tersebut. 
Pemberian indikator dalam pembelajaran mengacu pada hasil belajar yang harus dikuasai siswa.Dalam pencapaian hasil belajar siswa, guru dituntut untuk memadukan ranah kognitif, afektif, dan psikomotor secara proporsional. Horward Kingsly membagi tiga macam hasil belajar, yakni (a) ketrampilan dan kebiasaan, pengetahuan dan pengertian,(c) sikap dan cita-cita. Masing-masing jenis hasil belajar dapat diisi dengan bahan yang telah ditetapkan dalam kurikulum.

Sedangkan Gagne membagi lima hasil belajar yakni (a) informasi verbal, (b) keterampilan verbal, (c) strategi kognitif, (d) sikap, dan (e) ketrampilan motoris.Dalam dalam sistem pendidikan nasional rumusan tujuan pendidikan, baik tujuan kurikuler maupun tujuan instraksional, menggunakan klasikfikasi hasil belajar dari Benyamin Bloom yang secara garis besar membaginya menjadi tiga ranah yakni ranah kognitif, ranah efektif, dan ranah pisikmotoris (Nana Sudjana, 2002).

Model pembelajaran make and match adalah system pembelajaran yang mengutamakan penanaman kemampuan social terutama kemampuan bekerja sama, kemampuan berinteraksi disamping kemampuan berfikir cepat melalui permainan mencari pasangan dengan dibantu kartu (Wahab 2007) model meke and match mencari paangan merupakan salah satu alternative yang dapat diterapkan kepada siswa. Penerapan metode ini dimulai dari teknik yaitu siswa disuruh mencari pasangan kartu yang merupakan jawaban/ soal sebelum batas waktu nya, siswa yang dapat mencocokan katunya di beri poin.

Suyatno (2009) mengungapkan bahwa model make and match adalah metode pembelajaran dimana guru menyiapkan kartu yang berisi soal atau permasalahan dan menyiapkan kartu jawaban kemudian siswa mencari pasangan kartunya. Model pembelajaran make and match merupakan bagian dari pembelajaran kooperatif. Model pembelajaran kooperatif didasarkan atas falsafah homo homini socius, falsafah ini menekankan bahwa manusia adalah mahluk social (Lie, 2003: 27). Model make and match melatih siswa untuk memiliki sikap social yang baik dan melatih kemampuan siswa dalam bekerja sama disamping melatih kecepatan berfikir siswa.

\section{METODE}

Jenis penelitian ini adalah penelitian tindakan (Suroto, dkk, 2017). Prosedur penelitian tindakan kelas ini merujuk pada dengan mengikuti model yang terdiri atas empat komponen pokok penelitian kelas yakni: 1) perencanaan (planning), 2) tindakan (acting), 3) pengamatan (observing), dan 4) refleksi (reflecting). Analisis data dalam penelitian tindakan kelas ini menggunakan analisis kuantitatif dan kualitatif (Supardi, 2006).Terhadap perolehan hasil belajar IPS dianalisis secara kuantitatif dengan memberikan nilai pada hasil belajar siswa.

\section{HASIL}

Telah diketahui bahwa subjek penelitian berjumlah 32 siswa.Pelaksanaan penelitian tindakan kelas ini dilakukan dalam 3 (tiga) siklus. Berikut disajikan paparan hasil penelitian yang terdiri atas hasil belajar IPS melalui kolaborasi model pembelajaran make and match dan hasil observasi terhadap proses pembelajaran.

Melalui model pembelajaran make and match diperoleh data untuk ketuntasan 76 sebanyak $50 \%$ atau 16 orang siswa. Sedangkan yang tidak tuntas sebesar 16 atau $50 \%$, dan rata-rata hasil belajar sebesar 75.Selengkapnya dapat dibaca pada tabel distribusi frekuensi bergolong sesuai dengan kategori hasil belajar bahwa perolehan hasil belajar melalui metode make and match Siklus I ketuntasan individual baru mencapai 13\%. Potret pembelajaran IPS belum mencapai tujuan yang diharapkan guru yang tertuang dalam indikator kinerja $>85 \%$ dari jumlah siswa dalam kelas telah mencapai ketuntasan belajar individual, sehingga perlu dilaksanakan siklus II. 
Pada siklus II melalui model pembelajaran make and match diperoleh data untuk ketuntasan 73 sebanyak 9 orang siswa tuntas atau 39.1\%. Sedangkan yang tidak tuntas sebesar 14 atau $60.9 \%$ dan rata-rata hasil belajar sebesar 64. Selengkapnya dapat dibaca pada tabel distribusi frekuensi bergolong sesuai dengan kategori hasil belajar bahwa perolehan hasil belajar melalui metode make and match Siklus II ketuntasan individual baru mencapai 84\%. Potret pembelajaran IPS sudah mencapai tujuan yang diharapkan guru yang tertuang dalam indikator kinerja > 85\% dari jumlah siswa dalam kelas telah mencapai ketuntasan belajar individual, sehingga untuk kesempurnaan perlu dilaksanakan siklus III.

Pada siklus III melalui model pembelajaran make and match diperoleh data untuk ketuntasan 73 sebanyak 20 orang siswa tuntas atau 87\%. dan rata-rata hasil belajar sebesar 81. Selengkapnya dapat dibaca pada tabel distribusi frekuensi bergolong sesuai dengan kategori hasil belajar bahwa perolehan hasil belajar melalui metode make and match Siklus III ketuntasan individual baru mencapai $87 \%$. Potret pembelajaran IPS sudah mencapai tujuan yang diharapkan guru yang tertuang dalam indikator kinerja > 85\% dari jumlah siswa dalam kelas telah mencapai ketuntasan belajar individual, sehingga sudah dapat ditarik kesimpulan dan menutup semua siklus.

\section{PEMBAHASAN}

Berdasarkan hasil penelitian diketahui bahwa terdapat peningkatan hasil belajar IPS materiusaha persiapan kemerdekaan dengan kompetensi dasar mendeskripsikan peristiwaperistiwa sekitar proklamasi dan proses terbentuknya Negara kesatuan republik Indonesia dan tujuan pembelajaran setelah belajar siswa mampu menjelaskan perbedaan perspektif antar kelompok sekitar proklamasi kemerdekaan indonesia, menjelaskan kronologi proklamasi kemerdekaan indonesia, mengidentifikasi penyebaran berita proklamasi kemerdekaan melalui berita radio, pamphlet dan selebaranm menjelaskan dukungan dari berbagai daerah berupa dukungan spontan dan tindakan heroik dari berbagai daerah. Kemudian juga perbaikan karakter siswa yang diharapkan memiliki semangat kebangsaan dan menghargai prestasi serta gemar membaca, melalui metode pembelajaran make and match.

Hal tersebut diindikasikan dari perolehan rata-rata untuk ketuntasan 73 sebanyak pada siklus I sebanyak 13\% tuntas dan pada siklus II sebanyak 39.1\% tuntas dan pada siklus III $87 \%$ tuntas.Potret pembelajaran IPS sudah mencapai tujuan yang diharapkan guru yang tertuang dalam indikator kinerja $>85 \%$ dari jumlah siswa dalam kelas telah mencapai ketuntasan belajar individual.

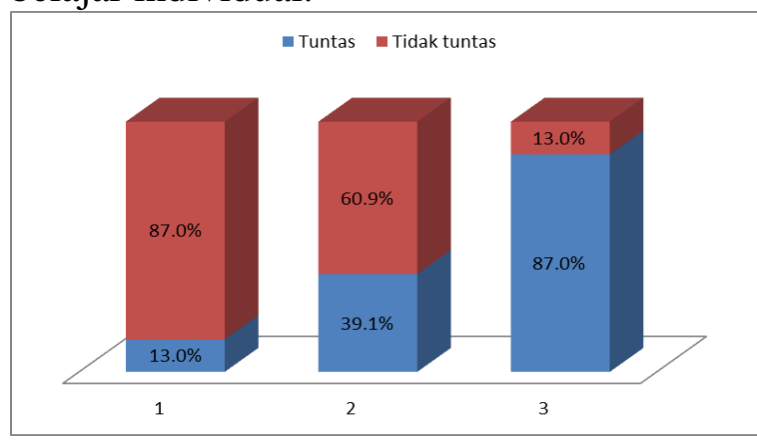

Terbukti bahwa dalam penelitian ini membuktikan bahwa penerapan metode make and match dapat meningkatkan kemampuan mendeskripsikan peristiwa sekitar proklamasi dengan sikap para siswa yang berangsur-angsur setelah belajar sejarah menimbulkan semangat kebangsaan dan juga menghargai prestasi dan gemar membaca sudah sesuai dari harapan, bahwa siswa memiliki semangat kebangsaan terhadap bangsa ini hal ini dilihat lebih optimis terhadap perkembangan bangsa dan juga lebih menghargai prestasi para pejuang yang telah memperjuangkan kemerdekaan yang ditunjukkan dari memperhatikan dan sudah mau mendengarkan materi pelajaran dan sudah mulai mau membaca bagi siswa dalam membaca sejarah.

Hasil penelitian ini mendukung penelitian terdahulu yang disampaikan oleh Indahwati, (2009) bahwa metode Make a match dapat meningkatkan aktivitas dan 
hasil belajar siswa, meskipun belum mencapai $100 \%$. Pada siklus 1 aktivitas belajar siswa dilihat dari proses pembelajaran mencapai $13 \%$ meningkat pada siklus 2 mencapai $39.1 \%$.

\section{SIMPULAN}

Terbukti bahwa dalam penelitian ini membuktikan bahwa penerapan metode make and match dapat meningkatkan kemampuan mendeskripsikan peristiwa sekitar proklamasi dengan sikap para siswa yang berangsur-angsur setelah belajar sejarah menimbulkan semangat kebangsaan dan juga menghargai prestasi dan gemar membaca sudah sesuai dari harapan, bahwa siswa memiliki semangat kebangsaan terhadap bangsa ini hal ini dilihat lebih optimis terhadap perkembangan bangsa dan juga lebih menghargai prestasi para pejuang yang telah memperjuangkan kemerdekaan yang ditunjukkan dari memperhatikan dan sudah mau mendengarkan materi pelajaran dan sudah mulai mau membaca bagi siswa dalam membaca sejarah.

\section{DAFTAR RUJUKAN}

Depdiknas. 2001. Buku 1 Manajemen Peningkatan Mutu Pendidikan Berbasis Sekolah. Jakarta: Depdiknas.

Indra Jati Sidi. 2004. Pelayanan Profesional, Kegiatan Belajar-Mengajar yang Efektif. Jakarta: Puskur Balitbang Depdiknas.

Indahwati, Nur. 2009. Penerapan Pembelajaran Kooperatif Metode Make Amatch untuk Meningkatkan Aktivitas dan Hasil Belajar Siswa Kelas XI IPS pada Mata Pelajaran Akuntansi Pokok Bahasan Jurnal Umum di SMA Kertanegara Malang.

Lie, Anita. 2004. Cooperative Learning. Grasindo. Jakarta
Nana Sudjana.2002. Penilaian Hasil Proses Belajar Mengajar. Bandung: Remaja Rosdakarya.

Puskur Balitbang Depdiknas. 2003. Modelmodel Pembelajaran Efektif. (www.puskur_balitbang_depdikna s.com).upadate 28 Agustus 2007.

Supardi, Suharsimi Arikunto, Suhardjono. 2006. Penelitian Tindakan Kelas. Yakarta: Bumi Aksara.

Suryosubroto. 2002. Proses Belajar Mengajar Di Sekolah. Jakarta: Rineka Cipta

Suyatno. 2009. Menjelajah Pembelajaran Inofatif. Masmedia Buana Pusaka. Sidoarjo.

Suroto, B., Novita, N., Pailis, E. A., Waldelmi, I., \& Fatkhurahman, F. (2017). Metode Penelitian Tindakan Solusi Bagi Masalah Sosial. Jurnal Diklat Review, 1(1), 25-28.

Wahab. 2007. Metode dan Model-Model Mengajar. Bandung: Alfabeta. 